\title{
Alfons Klafkowski
}

\section{Stolica Apostolska a ONZ}

Prawo Kanoniczne : kwartalnik prawno-historyczny 20/1-2, 87-99

1977

Artykuł został zdigitalizowany i opracowany do udostępnienia w internecie przez Muzeum Historii Polski w ramach prac podejmowanych na rzecz zapewnienia otwartego, powszechnego i trwałego dostępu do polskiego dorobku naukowego i kulturalnego. Artykuł jest umieszczony w kolekcji cyfrowej bazhum.muzhp.pl, gromadzącej zawartość polskich czasopism humanistycznych i społecznych.

Tekst jest udostępniony do wykorzystania w ramach dozwolonego użytku. 


\section{ALFONS KLAFKOWSKI}

\section{STOLICA APOSTOLSKA A ONZ}

Okres po II wojnie światowej jest nacechowany niezwykłą ruchliwością dyplomacji papieskiej. Można przyjąć sformulowanie Igino Cardinale, który stwierdził: „Pośrednim celem dyplomacji papieskiej są wszystkie problemy o charakterze moralnym i społecznym, jak również wszystko to, co może ułatwić rozwój współpracy między państwami i ich pokojowe współistnienie. Pod tym względem zadania dyplomacji papieskiej zbiegają się w pewnym sensie z zadaniami dyplomacji świeckiej, czyli polegają na chronieniu równowagi, pokoju i postępu między państwami..."1. Realizacja tych zadań dyplomacji papieskiej znalazła swój wyrazw kilku epokowych dokumentach papieskich, z których Encyklika Jana XXIII Pacem in terris jest dokumentem bez precedensu $w$ historii Stolicy Apostolskiej. Właśnie ta encyklika jest w szczególny sposób związana ze stosunkiem Stolicy Apostolskiej do ONZ. Kardynał Leo J. Suenens, wręczając encyklikę Pacem in terris Sekretarzowi Generalnemu ONZ w 1963 r. nazwal ją , listem otwartym do całego świata" 2. W przemówieniu tym nazwana została ta encyklika również „wspólnym mianownikiem między ludźmi dobrej woli". Encyklika Populorum Progressio wydana przez Pawła VI stanowi jakgdyby dopełnienie encykliki Pacem in terris ${ }^{3}$.

Udział Stolicy Apostolskiej w onganizacjach międzynarodowych oraz w licznych wiellkich konferencjach międzynarodowych stanowi więc realizację tych dwóch wielkich encyklik. Stanowi też potwierdzenie głównej tezy Pawła VI, który wielokrotnie określał zadania dyplomacji papieskiej jako ,sztukę organizowania pokoju" 4.

Aktywny i wszechstronny udział Stolicy Apostolskiej w powojennym ksztaltowaniu stosunków międzynarodowych został opra-

1 Igino Cardinale Stolica Swięta a dyplomacja (referat wygłoszony $z$ dinia 5.XII.1962 r.), - „Ż.cie i Myśl” $1963 \mathrm{Nr} 1-2$ s. $169 \longrightarrow 176$. Tutaj cyt. s. 169 .

2 Przemówienie $w$ ONZ (tłumaczenia oparte na publikacji przemówienia w "Osservatore Romano" z dnia 16.V.1973 r.) - „Życie i Mysl”" $1963 \mathrm{nr} 7-8$ s. $37-45$.

${ }^{3}$ Rudolf $\mathrm{K}$ ir s c h la ege r La presence $d u$ Saint-Siege facteur de paix dans la Communaute Internationale - "Osservatore Romano" Edition francaise 22 II 1974 s. $5-8$.

$4 \mathrm{~Pa}$ u l VI To Diplomatic Corps. Prophetic voice of the Church in the search for balance and peace. - "Osservatore Romano" 24.I.1974 $\mathrm{Nr}$ 4. Warto tutaj także zwrócić uwage na artykuł: Jan $\mathrm{Czaj}$ a Insty- 
cowany w dwóch dziełach, które stanowią fundament wszelkich naukowych rozważań na ten temat. Pierwsze $z$ nich, napisał szef protokołu w Sekretariacie Stanu Stolicy Apostolskiej, Igino Cardinale Le Saint-Siège et la Diplomatie w 1962 r. ${ }^{5}$. Jest to historyczny i prawny zarys zarówno założeń teoretycznych, jak i praktyki dyplomacji papieskiej. W nauce prawa międzynarodowego jest to pierwsze tego rodzaju dzielo, napisane przez kompetentnego przedstawiciela dyplomacji papieskiej. Drugie dzielo, to ogromna praca, którą napisal Heribert Franz Koeck pod tytulem Die voelkerrechtliche Stellung des Heiligen Stuhls, wydana w 1975 r. ${ }^{6}$. Ten wybitny prawnik austriacki, członek niejednej delegacji Stolicy Apostolskiej na wielkich konferencjach międzynarodowych, zebrał w swym dziele komplet źródeł w zakresie pozycji Stolicy Apostolskiej $w$ prawie międzynarodowym i $w$ stosunkach międzynarodowych — ze szczególnym i bardzo szerokim uwzględnieniem okresu po II wojnie światowej. Można powiedzieć, że jest to dzieło klasyczne, gdyż $\mathbf{z}$ punktu widzenia bibliografii na ten temat, ma ono niewątpliwie charakter zarówno bilansu dotychczasowego dorobku całej nauki w tym zakresie a jednocześnie stanowi przełomowe otwarcie do rozważań na nowych, współczesnych torach stosunków międzynarodowych. Te dwa dzieła pozwalają w sposób syntetyczny przedstawić również problem stosunków między Stolicą Apostolską a ONZ.

Szkicowe przedstawienie tego problemu wymaga omówienia następujących zagadnień:

I. Stolica Apostolska jako podmiot prawa miedzynarodowego.

II. Stolica Apostolska - Państwo Watykańskie a organizacje międzynarodowe.

III. Udział Stolicy Apostolskiej w pracach ONZ i organizacjach wyspecjalizowanych.

IV. Wnioski.

Przechodzę obecnie do przedstawienia tych szczególowych elementów problematyki stosunków między Stolicą Apostolską a ONZ.

\section{Stolica Apostolska jako podmiot prawa międzynarodowego}

Charakter prawny Stolicy Apostolskiej w płaszczyźnie prawa międzynarodowego jest zagadnieniem skomplikowanym i nietypowym. Określenie stosunku Stolicy Apostolskiej do ONZ wyma-

tucjonalne formy dzialania dyplomacji watykańskiej - „Sprawy Międzynarodowe" (Warszawa) $1976 \mathrm{Nr} 1$ s. 92-104.

5 Igino Cardinale Le Saint-Siege et la Diplomatie 1962 s. 342. Szczególowe omówienie tego dzieła: A. Kla f kow s k Prawo międzynarodowe a Stolica Apostolska - „Zycie i Mysl”" $1963 \mathrm{Nr} 11-12$ s. 132.

- Heribert Franz $\mathrm{K}$ oe ck Die voelkerrechtliche Stellung des Heiligen Stuhls Berlin 1975 s. 925 
ga jednak sformułowania tylko podstawowych cech Stolicy Apostolskiej jako podmiotu prawa międzynarodowego. Pojecie podmiotowości międzynardowej jest nierozdzielnie związane $z$ pojęciem suwerenności. Jeśli chodzi o tę cechę podmiotowości Stolicy Apostolskiej, to należy dokonać analizy trzech składników, które w zasadzie są nierozdzielne, a mimo to muszą być rozpatrywane w różnych płaszczyznach, a nie tylko w plaszczyźnie prawa międzynarodowego. Odrębnego omówienia prawnego wymaga przedstawienie pozycji: Kościoła Katoliakiego - Stolicy Apostolskiej oraz Państwa Watykańskiego.

Kościół Katolicki jest podmiotem prawa międzynarodowego wszakże - jak stwierdza I. Cardinale - jest to "organizm nietypowy" 7. Cardinale konstruuje analogię między Kościołem Katolickim a państwem, jakkolwiek dodaje, że pozycja Kościoła Katolickiego jest analogiczna, ale nie jest identyczna $z$ pozycja państwa. Papież, jako najwyższa władza Kościoła Katolickiego, wykonuje suwerenność duchową na podstawie prawa boskiego. Cardinale przytacza dwie opinie na poparcie swego stanowiska. Akty prawa międzynarodowego oddzielają pojęcie Kościoła Katolickiego ad pojęcia Sitolicy Apostolskiej. Warto zwrócić uwagę, że traktat lateraneński z dnia 11 lutego 1929 r. osobno reguluje w art. 1 położenie prawne religii katolickiej we Wloszech, osobno zaś w art. 2 uznaje suwerenność Stolicy Apostolskiej w stosunkach międzynarodowych. Zapewne można by przytoczyć więcej takich przykładów. Takie ujęcie pozycji prawnej Kościoła Katolickiego nie narusza konstrukcji jego suwerenności duchowej, tak jak ją formuluje Cardinale.

Stolica Apostolska - jest to termin określający zwierzchnią władzę w Kościele Katolickim ${ }^{8}$. Określenia tego używa się w trojakim znaczeniu. Po pierwsze - uważa się Stolicę Apostolską za centralne kierownictwo Kościoła Katolickiego, za instytucję, która działa przez swego nosiciela wladzy, Papieża. Po drugie - rozumie się pod tym pojęciem cały aparat władzy Kurii Rzymskiej $z$ papieżem na czele, (a więc wszystkie kongregacje, trybunały i urzędy). Po trzecie - pod pojęciem Stolicy Apostolskiej rozumie się najwyższą władzę następcy Swiętego Piotra, a więc pełnię wszelkiej władzy kierowniczej w Kościele Katolickim, uosobionej w Papieżu. Analiza tego pojęcia dokonana zarówno przez znawców prawa kanonicznego, jak i przez naukę prawa międzynarodowego pozwala ustalić, że w płaszczyźnie prawa międzynarodowego pod pojęciem Stolicy Apostolskiej należy rozumieć w szczególności Papieża jako zwierzchnią władzę w Kościele Kato-

7 Cardinale op. cit. s. 41.

s Szczególowa dokumentacja: A. Kl a fkowski Granica polsko-niemiecka a konkordaty $z$ lat 1929 i 1933 Warszawa 1958 s. 486 - tutaj cyt. s. $191-193$. 
lickim. $Z$ analizy tej wynikają również inne wnioski. Według kanonisty Stolica Apostolska „podobnie jak i Kościół jest ustanowienia boskiego. Te dwie instytucje, Kościól i Stolica Apostolska, pozostają z sobą $w$ tak ścisłej lączności, że tam gdzie jest jedna, tam jest $i$ druga. Stolica Apostolska $w$ swej działalności utożsamia się $\mathrm{z}$ Kościołem $\mathrm{i}$ jest jakby jego ucieleśnieniem. Jest ona $\mathrm{w}$ stosunku do Kościoła tym, czym forma w stosuniku do materii. Dlatego też i niezależność zupełna przysługująca Kościolowi winna jej również przysługiwać". Stolica Apostolska jest podmiotem prawa międzynarodowego powszechnie uznanym, jakkolwiek trudno zaprzeczyć istnieniu różnic uzasadniających tę podmiotowość. Podstawę prawną pozycji Stolicy Apostolskiej stanowi lkanon 7 kodeksu prawa kanonicznego. Mówiąc o władzy papieża określa ją jakko „a quavis humana auctoritate independens". Kanon $100 \S 1$ stwierdza: "Catholica Ecclesia et Apostolica Sedes moralis personae rationem habent ex ipsa ordinatione divina". List Piusa XI analizujący zagadnienie suwerenności Stolicy Apostolskiej na tle umów zawieranych z Włochami w 1929 r. podkreśla, że „w konkordacie stają naprzeciw siebie jeżeli nie dwa państwa, to $\mathrm{z}$ wszelką pewnością dwie suwerenności, w całej pełni takie, to jest zupełnie doskonałe, każda w swoim porządku". Pius XI podkreśla również w tym liście, że papież, „najwyższa i suwerenna władza Kościola, rozporządza tym, co podług jego zdania może i winno być zrobione dla większej chwały Boga i większego dobra dusz". W przeciwieństwie do specjalistów prawa kanonicznego $w$ nauce prawa międzynarodowego poglądy na temat suwerenności Stolicy Apostolskiej są podzielone. Niezależnie jednak od tych różnic nauka prawa międzynarodowego nie może przyjąć innej podstawy konstruowania suwerenności Stolicy Apostolskiej niż ta, która jest zawarta w kodeksie prawa kanonicznego. Takie stanowisko nauki prawa międzynarodowego jest zgodne $\mathrm{z}$ historycznym procesem kształtowania Stolicy Apostolskiej jako podmiotu prawa międzynarodowego. Państwo Watykańskie jest świeckim elementem suwerenności Stolicy Apostolskiej, którą zgodnie $z$ art. 3 traiktatu lateraneńskiego, sprawuje nad nim „nieograniczoną własność i wyłączną oraz absolutną wladzę i jurysdykcję suwerenną..." 9.

Te pozornie teoretyczne rozważania o charakterze podmiotowości międzynarodowej Stolicy Apostolskiej, mają zasadnicze znaczenie praktyczne $\mathrm{w}$ stosunkach międzynarodowych. Warto podkreślić, że taki organ pomocniczy ONZ, jalk Komisja Prawa Międzynarodowego ONZ nie miała żadnych wahań $w$ toku prac kodyfikacyjnych nad projektem konwencji o prawie traktatów i zaliczyla Stolice Apostolska do ,innych podmiotów prawa międzynarodowego" - w pełni uznając zdolność traktatową Stolicy Apostol-

C Cardina le op. cit. s. $51-62$. 
skiej. Komisja Prawa Międzynarodowego ONZ zajęła stanowisko, że umowy międzynarodowe zawierane przez Papieża są wyrazem nie tyle suwerenności terytorialnej Państwa Watykańskıego, lecz zdolności traktatowej Stolicy Apostolskiej, istniejącej niezależnie od Państwa Watykańskiego 10. W tym świetle trafna jest konkluzja jednej $z$ najnowszych polskich prac na ten temat, stwierdzająca: „...Obecnie nikt nie kwestionuje tego, że Stolica Apostolska ma osobowość prawną prawa międzynarodowego nie tylko jako najwyższy organ Państwa Watykańskiego, ale także jako najwyższa władza Kościoła Kiatolickiego" 11.

\section{Stolica Apostolska - Państwo Watykańskie a organizacje międzynrodowe}

Terminologia t. zw. obecności Stolicy Apostolskiej w stosunkach z organizacjami międzynarodowymi stanowi problem, któremu $H$. F. Koeck poświęca w swej pracy dużo uwagi i omawia źródła dotąd $w$ pracach naukowych nie uwzględnione ${ }^{12}$. Problem sprowadza do wyjaśnienia, czy w organizacjach międzynarodowych formalnie bierze udzial Stolica Apostolska, czy też Państwo Watykańskie (zwane bardzo często po prostu Watykanem). W działalności ONZ i w dokumentacji ONZ pojawił się początkowo termin „Watykan". W ten sposób mogło powstać wrażenie, że pod pojęciem „Watykan" rozumie się t. zw. karłowate państwo, które nie jest członkiem ONZ, lecz usiłuje brać udzial w pracach tej organizacji. Przeciwko formowaniu się tego wrażenia wystąpiła Stolica Apostolska. Wskutek różnych wyjaśnień w tym zakresie Sekretarz Generalny ONZ złożył w Genewie w 1957 r. oświadczenie, stwierdzające: „Jeżeli zabiegam o audiencję w Watykanie to nie dlatego, że pragnę spotkać się z królem Państwa Watykańskiego, lecz by być przyjętym przez głowę Kościoła Katolickiego". Kilka miesięcy później nastąpiła w okresie 16-18 październịa 1957 r. wymiana not między Sekretarzem Generalnym ONZ a Stolicą Apostolską, w wynilku której do dokumentów ONZ wprowadzone zostało prawidłowe określenie "Stolica Apostclska" zamiast dotychczasowego terminu "Watykan". Jest to oczywiście problem wychodzący daleko poza zagadnienia protokolarne i zasługujacy z tego względu na szczegółowe omówienie.

Skutki tej wymiany not między Stolicą Apostolską a Sekreta-

${ }_{10}^{10}$ Dok. A/CN/4/144/ 26.111 .1962 s. $147+24$. Tutaj cyt. s. 17 oraz. s. 31 .

${ }^{11}$ Tadeusz W lodarczy $\mathrm{k}$ Konkordaty. Zarys historii ze szczególnym uwzględnieniem XX wieku. Warszawa 1974 s. 549. Tutaj cyt. s. 23.

$12 \mathrm{~K}$ o e c $\mathrm{k}$ op. cit. s. $782-783$. 
rzem Generalnym ONZ miały aczywiście szerszy zasięg niż sama ONZ. W ślad za tą korektą nazwy Stolicy Apostolskiej w dokumentacji ONZ poszly również zmiany $w$ innych organizacjach międzynarodowych, a zwłaszcza w organizacjach wyspecjalizowanych, stanowiących t. $z w$. rodzinę ONZ. W ten sposób poczynając od 1957 r. Stolica Apostolska jako pelny podmiot prawa międzynarodowego i jako reprezentacja Kościoła Katolickiego weszła zarówno do obrotu prawnego w organizacjach międzynarodowych, jak i do udziału w tych konferencjach międzynarodowych, które ją interesowały ${ }^{13}$.

Pewne refleksy tych komplikacji, pozornie protokolarnych, można znaleźć w orędziu Pawła VI do Narodów Świata, wygłoszonym na posiedzeniu Zgromadzenia Ogólnego $\mathrm{ONZ}$ w dniu 4 października 1965 r. Paweł VI mówił wtedy $m$. in.: „...To spotkanie, zdajecie sobie wszyscy $z$ tego sprawę, posiada podwójną cechę: prostoty i równocześnie wielkości. Prostoty, bo ten który do was przemawia jest człowiekiem, jak i wy, jest waszym bratem; owszem, $z$ pośród was reprezentujących państwa suwerenne jest jednym z najmniejszych, któremu, jeśli zechcecie go uważać za przedstawiciela państwa, przysługuje drobniutka i prawie symboliczna suwerenność doczesna, stanowiąca minimum konieczne do zapewnienia mu wolności w wykonywaniu jego misji duchowej i przekonywająca każdego, kto $\mathrm{z}$ nim wchodzi w kontakt, że jest niezależny od wszelkiej władzy tego świata. Nie ma on żadnej potęgi świeckiej, nie ma żadnej pretensji do wspókzawodnictwa $z$ wami..." 14 .

Jest rzeczą oczywistą, że również w działalności dyplomacji papieskiej $w$ organizacjach międzynarodowych występuje i utrzymuje się podział na zainteresowanie tymi organizacjami w większej mierze bądź przez Stolicę Apostolską, bądź przez Państwo Watykańskie. W przytoczonej tutaj pracy I. Cardinale zachowany jest podział na szczególne zainteresowania bądź Stolicy Apostolskiej, bądź Państwa Watykańskiego w pracach różnych organizacji międzynarodowych ${ }^{15}$. Warto tutaj podkreslić, że ONZ oraz wszystkie organizacje wyspecjalizowane wykazane są przez Cardinale w tej grupie, które przeważnie - jeśli nie wyłącznie - interesują Stolicę Apostolską.

18 Heribert Franz Koeck Rechtsfragen der Teilnahme des $\mathrm{Hl}$. Stuhls an internstionalen Institutionen - Oesterreichisches Archiv fuer Kirchenrecht 1974 H. 2 s. 156-178. Tutaj cyt. s. 168-170.

14 Orędzie Pawla VI do Narodów Zjednoczonych cytowane jest tutaj wedlug przekładu opublikowanego w ,Kierunkach” (Warszawa) 1965 $\mathrm{Nr} 42$.

15 Cardina le op. cit. s. $23-24$ oraz s. $78-81$. 


\section{Udział Stolicy Apostolskiej w pracach ONZ i organizacjach wyspecjalizowanych}

Współczesne stoisunki międzynarodowe cechuje dynamiczny, niezwykły rozwój organizacji międzynarodowych wszelkiego rodzaju. Bardzo często można spotkać się $z$ porównywaniem udziału Stolicy Apostolskiej $w$ działalności organizacji międzynarodowych $w$ okresach po I wojnie światowej i po II wojnie światowej. Trzeba jednak stwierdzić, że te dwa okresy nie są porównywalne. $Z$ punktu widzenia udziału Stolicy Apostolskiej w pracach organizacji międzynarodowych jedną cezurę stanowi na pewno traktat lateraneński z 1929 r. - a więc umowa międzynarodowa, która przywraca istmienie Państwa Watykańskiego 16.

Koncentrując uwage na stosunku Stolicy Apostolskiej do ONZ należy przede wszystkim stwierdzić, że ani Stolica Apostolska, ani Państwo Watykańskie nie są do dziś członkami ONZ. Cardinale uzasadnia to $w$ jednym zdaniu stwierdzając, że do funkcji papieża nie należy rozcinanie 'konfliktów politycznych, gospodarczych, czy handlowych między państwami ${ }^{17}$. Nie oznacza to wszakże jakoby Stolica Apostolska była obojętna na fakt istnienia ONZ lub jej działalność. Koeck przedstawia po raz pierwszy - jedyną w swoim rodzaju szczególową dokumentację - która stanowi dowód niezwykle bliskiego zainteresowania Stolicy Apostolskiej okresem pre przygotowawczych do pawstania ONZ 18 . Z tej dakumentacji wynika równiez, że pontyfilkaty trzech kolejnych papieży: Piusa XII, Jana XXIII i Pawła VI stanowią okresy niezwykle i:tensywnego zainteresowania Stolicy Apastolskiej działalnością ONZ. Dokumentacja zawarta w klasycznym dziele Koecka wykazuje tendencje. Stolicy Apostolskiej do bezpośredniego wręcz działania w kierunku nadania powstającej ONZ charakteru organizacji międzynarodowej możliwie najbardziej demokratycznej, gwarantującej przestrzeganie zasady suwerenności i równości wszystkich państw, zarówno czlonków założycieli tej organizacji, jak i jej przyszłych członków, do tej organizacji przyjmowanych. Wynika $z$ tej dokumentacji, że synchronizacja działalności Stolicy Apostolskiej oraz konferencji biskupów wielu państw demokratycznych była w 1945 r. posunięta rzeczywiście bardzo daleko. Nie było to zreszta zainteresowanie o charakterze teoretycznym, czy téz wy-

16 Oparte na publikacji: prof. Stephan Verosta International Organisations, The Holy See and World Peace zawartej $w$ sprawozdaniu Permanent Mission of the Holy See to the IAEA and to the UNIDO. Vienna - Austria. Day of Peace 1972 wydanym przez Nuncjature Apastolską $\mathrm{w}$ Wiedniu. Wstępne przemówienie Nuncjusza Apostolskiego Msgr. Oriano Quilici.

${ }^{17} \mathrm{Ca}$ r din a l e op. cit. s. 78, s. 81.

${ }^{18} \mathrm{~K}$ oe c k ap. cit. S. $698-719$. Jest to jedyna opublikowana dotad tak szczegółowa dokumentacja dotycząca tego problemu. 
łącznie pryncypialnym. Stolica Apostolska angażowala się praktycznie na wszystkich odcinkach reorganizacji społeczności międzynarodowej po II wojnie światowej. Warto tutaj dodać, że dokumentacja zebrana usystematyzowana i skomentowana przez Koecka stanowi pierwsze tego rodzaju opublikowane oświadczenie. Wiele dokumentów, które $\mathrm{w}$ tym zakresie cytuje nie zostało dotąd opublikowanych. Wszystkie te wysiłki znajdują swój szczególny wyraz w Encyklice Jana XXIII Pacem in terris $z$ dnia 11 kwietnia 1963 r. oraz w Encyklice Pawła VI Populorum progressio.

Podsumowanie tej linii działalności Stolicy Apostolskiej jest zawarte $\mathrm{w}$ oświadczeniu Pawła VI, skierowanym do Narodów Zjednoczonych $w$ czasie jego wizyty na sesji Zgromadzenia Ogólnego ONZ w 1965 r. Papież Paweł VI oświadczył wtedy: „....Nie mamy żadnej potęgi świeckiej, nie mamy żadnych pretensji do współzawodniczenia $z$ wami. $W$ istocie niczego od was nie żądamy, przeciwko niczemu nie powstajemy, chcemy tylko wyrazić pragnienie i prosić o pozwolenie byśmy mogli wam służyć w tym, do czego jesteśmy powołani, czyniąc to $z$ całkowitą bezinteresownością, pokorą i miłością...". Paweł VI podkreślił w swoim oświadczeniu: ,...Oreqdzie to wypływa $\mathrm{z}$ naszego długiego doświadczenia historycznego. Jako eksperci w sprawie ludzkości przynosimy tej organizacji uznanie naszych ostatnich poprzedników, całego Episkopatu Katolickiego i nasze w.łasne, w tym przekonaniu, że ta organizacja wyraża słuszną drogę współczesnej cywilizacji i światowego poikoju...". Podkreślając, że państwa zwracają się do ONZ jako do ostatniej nadziei, zgody i pokoju w świecie, Pawel VI stwierdził: ,...Istniejecie i pracujecie po to, by lączyć narody, by zespalać państwa; użyjmy wyrażenia: by wiązać jednych $z$ drugimi. Wy jesteście stowarzyszeniem. Jesteście pomostem między narodami. Jesteście siatką nawiązujących się między państwami stosunków. Bylibyśmy skłonni powiedzié, że to, co stanowi charakterystyczną cechę waszej organizacji stanowi też pewnego rodzaju odbicie w porządku doczesnym tego, czym nasz Kościół Katolicki pragnie być $\mathrm{w}$ porządku duchowym, to znaczy - jednym i powszechnym...". Pod koniec tego orędzia, wygłoszonego na posiedzeniu Zgromadzenia Ogólnego ONZ Paweł VI oświadczył: „...Panowie dokonaliście i dokonujecie wielkiego dzieła: wychowania ludzkości dla pokoju. ONZ jest szkolą tego wychowania. To jest właśnie ta aula magna tej szkoły. Każdy kto zasiada tutaj, staje się uczniem i mistrzem w sztuce budowania pokoju. A kiedy wychodzicie $z$ tej auli świat patrzy na was jak na architektów, jak na budowniczych pokoju. Wiecie o tym, że pokoju nie buduje się jedynie poprzez politykę oraz równowage sił i interesów, ale poprzez ducha, idee i dzieła pokoju. Wy jesteście zaangażowani $w$ to 'wielkie dzieło. Jesteście jednak dopiero na początku waszego trudu". Można powiedzieć, że orędzie Pawła VI wygłoszone ww 
1965 r. na sesji Zgromadzenia Ogólnego ONZ stanowi syntezę filozofii Stolicy Apostolskiej jeśli chodzi o określenje jej stosun'ku do tej organizacji międzynarodowej.

Orędzie Pawła VI ma tym większe znaczenie, że na początek pontyfikatu tego papieża przypada przełom $w$ stosunku Stolicy Apostolskiej do ONZ. Należy przypomnieć, że w dniu 21 marca 1964 r. Paweł VI oświadczył Sekretarzowi Generalnemu ONZ, że Stolica Apostolska chce być reprezentowana $w$ siedzibie $O N Z w$ Nowym Jorku przez stalego obserwatora. Oznacza to, że Stolica Apostolska, jakkolwiek nie będąc członkiem ONZ, nawiązuje stały codzienny kontakt $z$ działalnością tej organizacji przez swego stałego obserwatora. Może on odtąd zabierać glos w różnych organach ONZ, nie mając wszakże prawa głosowania w tych organach 19 .

Stolica Apostolska śledzi ze szczególną uwagą te działy stosunków międzynarodowych, które wchodzą w zakres t. zw. organizacji wyspecjalizowanych, zwanych także ,rodziną ONZ”. Przedstawiciele Stolicy Apostolskiej biorą czynny udział w rozwiązywaniu wielu zagadnień specjalistycznych, przy czym ich współpraca $z$ organizacjami wyspecjalizowanymi ma również charakter dzialania de lege feranda 20.

Rozpatrując to zagadnienie chronologicznie należy w pierwszym rzędzie zwrócić uwagę na działalność Stolicy Apostolsikiej w tego typu organizacjach międzynarodowych bezpośrednio po zakończeniu dzialań w II wojnie światowej. $\mathrm{Na}$ pierwszy plan wysunęla się wtedy kwestia arganizowania pomocy dla setek tysięcy uchodźców - którą to działalnością zajmowania się organizacja.międzynarodowa IRO. Stolica Apostolska brała udział w pracach tej organizacji od końca 1946 r. łącznie z tym okresem, w którym działalność IRO została poddana koordynacji w ramach Rady Gospodarczej i Społecznej ONZ. Stolica Apostolska podjęła również szyblko i bezpośrednio współpracę z FAO. W następnym etapie nawiązała Stolica Apostolska ścisły kontakt z UNESCO - wysyłając do tej organizacji swego stałego obserwatora, 'którym był nuncjusz papieski w Paryżu, późniejszy Papież Jan XXIII. W tym samym okresie Stolica Apostolska podjęła ścisłą współpracę z WHO. Papież Pius XII poświęcał $w$ tym okresie wiele uwagi problematyce pokojowego wykorzystania energii atomowej. Wyrazem tego jest udzial Stolicy Apostolskiej w pracach wszystkich organów międzynarodowych, działających na odcinku pokojowego wylkorzystania energii atomowej - włącznie z zatwierdzeniem przez Stolicę Apostolską statutu Międzynarodowej Agencji Energii Atomowej. W tym

${ }^{19} \mathrm{Koeck}$ op. cit. s. 720-732. Jest to omówienie kompletne dokumentacji dotyczącej ustanowienia stałego obserwatora Stolicy Apostolskiej prizy ONZ w Nowym Jorku.

${ }_{20}^{2}$ Verost a op. cit. s. $3-8$. 
okresie Stolica Apostolska śledziła ze szczególną uwagą wszystkie odcinki działalności Rady Gospodarczej i Społecznej ONZ, współdziałając $z$ tym organem głównym ONZ i udzielając mu w wielu sytuacjach czynnej pomocy.

Uzupełnieniem tej działalności Stolicy Apostolskiej w pracach t. zw. organizacji wyspecjalizowanych byl udzial Stolicy Apostolskiej $\mathrm{w}$ pracach przygotowawczych różnych organów międzynarodowych - które po latach przybrały kształt stałych organizacji wyspecjalizowanych - działających na odcinku skomplikowanych problemów gospodarczych, politycznych i społecznych państw t. zw. trzeciego świata. Warto podkreślić, że nie było takiej wielkiej konferencji międzynarodowej związanej $z$ tą problematyką, w której Stolica Apostolska nie brałaby udziału.

$\mathrm{Na}$ asobną uwagę zasługuje udział Stolicy Apostolskiej w wielkich konferencjach dyplomatycznych, zwoływanych w płaszczyźnie ONZ. Na szczególną uwagę zasługuje udział Stolicy Apostolskiej w konferencjach międzynarodowych, których celem była kodyfikacja prawa dyplomatycznego. $W$ tym kontekście należy wymienić konwencję wiedeńską o stosunkach dyplomatycznych z 1961 r., konwencję wiedeńską o stosunkach konsularnych z $1963 \mathrm{r}$. oraz konwencję wiedeńską 0 stosunkach państw $z$ organizacjami międzynarodowymi z $1975 \mathrm{r}$. Stolica Apostolska brała aktywny udział $\mathrm{w}$ tych konferencjach, których wynikiem były wymienione konwencje międzynarodowe. Należy też podkreślić aktywny udział Stolicy Apostolskiej $\mathrm{w}$ tych konferencjach wiedeńskich, w których wyniku powstała konwencja o prawie traktatów z $1969 \mathrm{r}$.

$\mathrm{Na}$ rozległym polu dyplomacji multilateralnej związanej glównie $z$ problematyką t. $z w$. trzeciego świata Stolica Apostolska brala aktywny udzial $\mathrm{w}$ tej działalności, która znalazła swe rozwiązanie $w$ powołaniu UNCTAD i UNIDO. Jak wiadomo sa to organizacje międzynarodowe - względnie organy międzynarodowe - charakterze uniwersalnym. Ogarniają one dosłownie cały świat, a ich konferencje stanowią centrum zainteresowania międzynarodowego $\mathrm{z}$ tego względu, że udział $\mathrm{w}$ tych konferencjach bierze przeciętnie 130-140 państw. Wśród nich jest oczywiście także Stolica Apostolska.

Przechodząc do systematyki udziału Stolicy Apostolskiej w pracach ONZ i w działalności organizacji wyspecjalizowanych oraz $w$ wielkich konferencjach międxynarodowych warto skorzystać z wyników, które osiągnął Koøck w swej klasycznej rozprawie 21.

${ }^{21} \mathrm{~K}$ oe c k op. cit. s. 750-772. Jest to jedyne $\mathrm{w}$ światowej literaturze przedmiotu usystematyzowane przedstawienie udziału Stolicy Apostolskiej $w$ organizacjach międzynarodowych. Wielkim osiągnięciem naukowym Koecka jest nie tylko zebranie dokumentów dotąd riedostępnych, lecz przede wszystkim takie ich usystematyzowanie, które $z$ tej 
Udział Stolicy Apostolskiej $\mathrm{w}$ tej działalności międzynarodowej występuje $w$ różnych formach.

Po pierwsze - jest to udział $w$ charakterze czlonka danej organizacji międzynarodowej. Należy odrazu dodać, że Stolica Apostolska nie była członkiem Ligi Narodów i nie jest czlonkiem ONZ. Jakko czlonek występuje Stolica Apostolska w dwóch organizacjach związanych ściśle $z$ ONZ, a mianowicie w: UNCTAD i UNIDO. Stolica Apostolska jest ponadto członkiem dwóch organizacji wyspecjalizowanych: ITU i UPU. Jest również członkiem IAEA, która wprawdzie nie jest organizacją wyspecjalizowaną ONZ, lecz jest uważana za członka t. zw. rodziny ONZ. Ponadto Stolica Apostolska jest członkiem kilku t. zw. rad specjalistycznych oraz organizacji międzyrządowych, ściśle związanych z ONZ. Jest rzeczą oczywistą, że jako członek tych organizacji międzynarodowych Stolica Apostolska rozwija działalność przede wszystkim w zakresie swych szczególnych, specyficznych zainteresowań. Jako członek organizaciji międzynarodowych, względnie organów międzynarodowych działa Stolica Apostolska poprzez swoich delegatów, korzystających ze statutu przedstawicieli dyplomatycznych.

Po drugie - Stolica Apostolska dziala w organizacjach międzynarodowych poprzez swoich stałych obserwatorów. W takim charakterze rozwija Stolica Apostolska działalność w Biurze ONZ w Genewie oraz w centralnym sekretariacie ONZ w Nowym Jorku. Taki stały obserwator obejmuje swoją działalnością również różne organizacje wyspecjalizowane oraz specjalistyczne organy międzynarodowe. Funkcje stałego abserwatora Stolicy Apostolskiej obejmują wykonywanie pełnej działalności w ramach danej organizacji międzynarodowej $\mathrm{z}$ wyłączeniem prawa do głosowania.

Po trzecie - Stolica Apostolska działa również w stosunkach międzynarodowych poprzez specjalne misje dyplomatyczne, nazywane także stałymi przedstawicielami lub specjalnymi przedstawicielstwami. W tym charakterze rozwija Stolica Apostolska działalność w pracach Rady Europejskiej w Strasburgu oraz w różnych t. zw. wspólnotach europejskich w Brukseli.

Po czwarte - Stolica Apostolska rozwija wreszcie działalność $\mathrm{w}$ charakterze t. $\mathrm{zw}$. wolnej współpracy $\mathrm{z}$ różnymi organizacjami międzynarodowymi (w tym także w ramach Międzynarodowej Organizacji Czerwonego Krzyża).

Niezależnie od charakteru czy też rodzaju działalności Stolicy Apostolskiej występuje ona we wszystkich tych przypadkach zawsze jako Stolica. Apostolska. W ten sposób, niezależnie od powszechnego uznania podmiotowości międzynarodowej Stolicy Apostolskiej, podkreślony jest również szczególny charakter Stolicy

części dzieła Koecka czyni prace klasyczną w nauce prawa międzynarodowego.

7 - Prawo kanoniczne 
Apastolskiej jako organizacji centralnej i nadrzędnej Kościola Katolickiego. Można stwierdzić, że podkreślenie tego charakteru ulega wzmocnieniu w stosunkach międzynarodowych. Szczególnym tego wyrazem jest udzial Stolicy Apostolskiej w konferencji bezpieczeństwa i wspólpracy w Helsinlkach. Przedstawiciel Stolicy Apostolskiej brał nie tylko aktywny udział w pracach tej konferencji, lecz również w jej punkcie kulminacyjnym objął przewodnictwo na plenum tej konferencji. Jest to tym bardziej wymowne, że była to konferencja regionalna o charakterze bez precedensu $w$ historii stosunków europejskich - w dodatku z udzialem dwóch mocarstw z poza Europy, a mianowicie Stanów Zjednoczonych i Kanady.

\section{Wnioski}

Przedistawiona wyżej problematylka stosunków między Stolicą Apostolską a ONZ nasuwa pewne wnioski, które - być może niekoniecznie są związane wyłącznie z tym tylko układem stosunków. Cardinale w swym referacie, wygloszonym w 1962 r. pt. Stolica Swięta a dyplomacja podkreślił na wstępie, że zadania Stolicy Apostolskiej na polu dyplomacji międzynarodowej są obecnie o wiele trudniejsze niż w średniowieczu. Wtedy byl tylko jeden cesarz i tylko jedna wspólnota narodów chrześcijańskich, które spontanicznie zwracały się wyłącznie do Papieża. Obecnie systemy politycznie i prawne wielu państw, dawnych i nowych, są często sprzeczne między sobą i często sprzeczne także w ich stosuniku do Stolicy Apostolskiej. Cardinale oświadczył w tym kontekście: „O dyplomacji Stolicy \$więtej wyglaszano najbardziej sprzeczne opinie. Jedni uważają ją za ,najlepszą w świecie”, inni twierdzą, ¿̇ż jest „przestanzała i anachroniczna”. Niektórzy uważają ją za potężny środek ułatwiający papiestwu oddziaływania na bieg polityki światowej i niemal utrwalający jego dawną pozycję najwyższego arbitra losów narodów. Jeszcze innym wydaje się, że dyplomacja jest niegodna Kościoła, który nie powinien stosować zmiennych i przebiegłych spasobów używanych i wykorzystywanych przez pańtwa w celu narzucenia własnych racji i własnej siły narodom. Są wreszcie i tacy, którzy uważają ją ze bezprawną ingerencję obcego kraju $\mathrm{w}$ wewnętrzne życie innego państwa, oraz tacy, zdaniem których dyplomacja Stolicy Swiętej jest obrazą miejscowej hierarchii kościelnej, której można by powierzyć przeprowadzanie negocjacji dyplomatycznych, jakimi zajmuje się przedstawiciel Stolicy Swiętej..." 22.

$\mathrm{Z}$ metodologicznego punktu widzenia warto zwrócić uwage na fakt, ze wszelkie rozważania na temat pozycji Stolicy Apostolskiej

22 C a rdinale Stolica Swięta a dyplomacja op. cit. s. 168. 
w prawie międzynarodowym oparte są na zastosowaniu metody indukcyjnej, a więc na wyciąganiu wniosków $z$ ogromnej dokumentacji międzynarodowej - zarówno w dziedzinie stosunków politycznych, jak i stosunków prawnych. Cała ta dokumentacja dowodzi w sposób nie do podważenia, że Stolica Apostolska jest podmiotem prawa międzynarodowego. Odpadają $w$ tym stwierdzeniu wszystkie przymiotniki w rodzaju - „normalnym”, „pelnym” itp. Stolica Apostolska jest podmiotem prawa międzynarodowego takim samym jak wszystkie inne podmioty $w$ tym systemie prawnym.

Cechą szczególną Stolicy Apostolskiej jako podmiotu prawa międzynarodowego jest tylko ta okoliczność, że posiada na niejako podwójną rolę w tej podmiotowści: Stolica Apostolska jest jednocześnie suwerenem $\mathrm{w}$ sensie materialnym $\mathrm{i}$ jednocześnie jest suwerenem w sensie duchowym - jako najwyższa władza w Kościele Katolickim. Szczególna rola Stolicy Apostolskiej w stosunkach międzynarodowych i w prawie międzynarodowym wyraża się tylko w tym jej podwójnym aspekcie. 